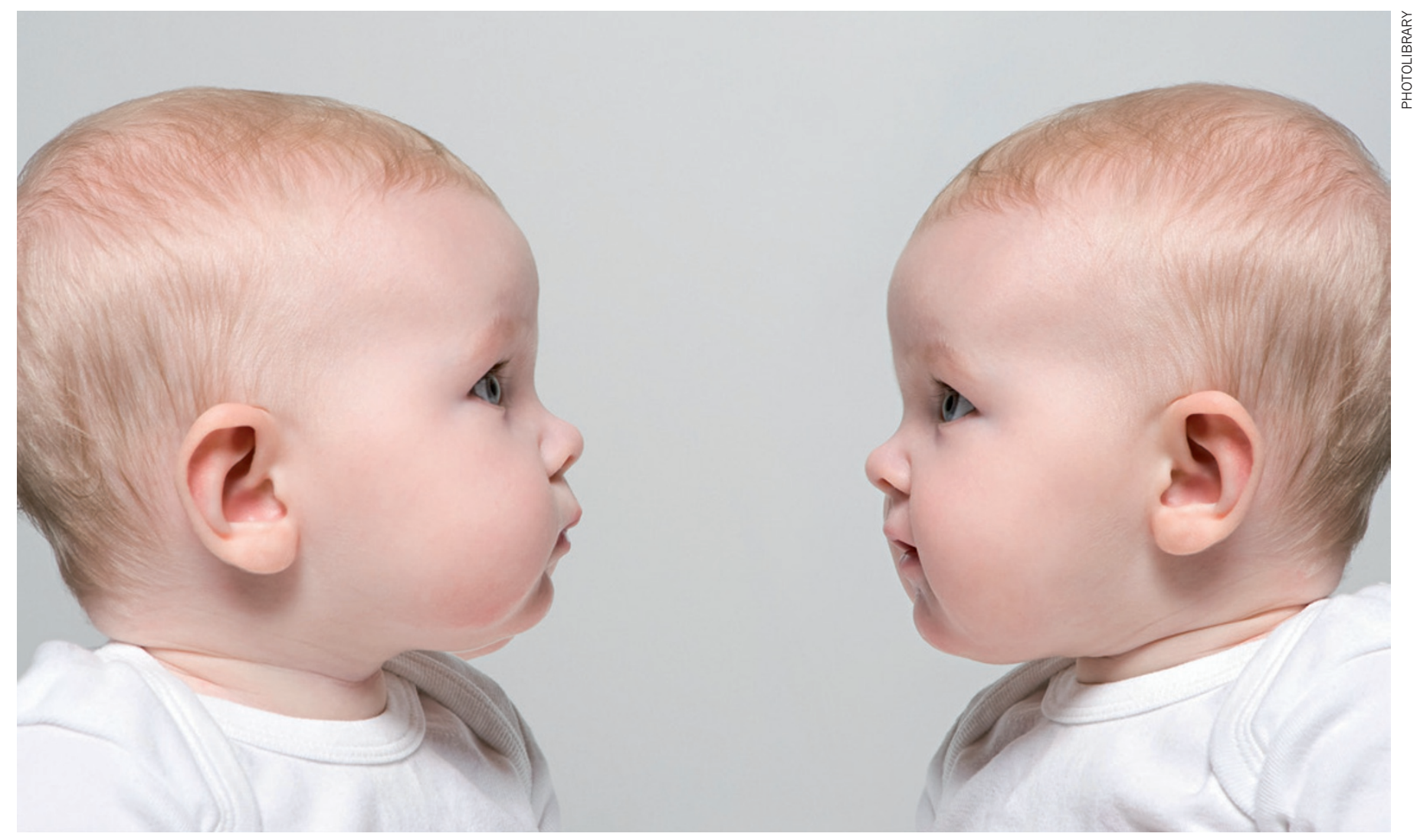

Inherited and environmental factors can switch genes on and off to give each of us, including monozygotic twins, a unique identity.

\title{
Beyond face value
}

\section{Jonathan Weitzman relishes two accounts of how environment can influence the script of our genome.}

A s an identical twin, I have always been fascinated by what determines who we are. Nature's clones are never truly identical, so what explains the differences between my brother and myself? How much of our identity is inherited; how much acquired by interacting with the environment? The field of epigenetics, standing at the interface between our environment and our genes, is beginning to offer answers.

Epigenetics explores how genetically identical entities, whether cells or whole organisms, display different characteristics, and how these are inherited. The past century witnessed amazing advances in our understanding of genetics, but secrets remain hidden within the genome. Epigenetics research is now blossoming, offering a potential panacea for these post-genome blues.

Two timely books open up this emergent field: Epigenetics by Richard Francis and The Epigenetics Revolution by Nessa
Epigenetics: The Ultimate Mystery of Inheritance

RICHARD C. FRANCIS

W. W. Norton: 2011.224 pp. £19.99, \$25.95

The Epigenetics Revolution: How Modern Biology is Rewriting Our Understanding of Genetics, Disease and Inheritance

NESSA CAREY

Icon Books: 2011. 320 pp. £17.99

Carey offer very different takes. Francis's thoughtful and succinct book focuses on the narrative and the excitement of discovery, rather than on the nitty-gritty details at the molecular level. His personal tour includes anecdotes from his travels around the world and allusions to popular culture.

Carey's book is more DNA-centric, focusing on epigenetic mechanisms and the chemistry of chromatin, which defines how DNA is packaged around proteins in the nucleus. Her book combines an easy style with a textbook's thoroughness.
Conveying epigenetics to a broad readership presents challenges. The field is in flux and the concepts are abstract and technically demanding. Researchers struggle to come up with a unanimously accepted definition of the term epigenetics. And there is confusion in the literature between epigenetic phenomena and epigenetic mechanisms. The first describes the transmission of heritable characteristics, thereby resembling genetics; the second focuses on how genes are regulated, and is more aligned with molecular biology. Francis is interested in the modes of inheritance and how these are affected by environmental events. Carey refers more to the mechanistic events that change how genes are switched on and off without altering the genes themselves.

Epigenetics, for Francis, is a form of cellular control over $\checkmark$ NATURE.COM For Nature's special on the Human Genome at Ten: go.nature.com/ugle41 
gene activity. He presents the cell as a theatrical production, noting that the standard view - with genes as directors, proteins as actors and other biochemicals as stagehands - needs to be reassessed. As an alternative to the 'executive gene' idea, in which the genome is in control, he urges readers to think about the 'executive cell'. Francis relegates genes to members of the cast, and insists that they are regulated by, not regulators of, cellular states.

A seasoned science writer, Francis is at his best when describing abstract concepts in a historical context. A chapter on developmental biology reminds us that the idea that form emerges gradually during development (known as epigenesis) arose in

"What malkes

the field so

exciting is

that we have

new tools to

address old

questions."

response to an earlier concept, which held that form is predetermined from the beginning (preformationism). Francis cautions us not to fall into the trap of using the 'genetic blueprint' or 'genetic program' metaphors, which he sees as contemporary preformationism or genomic determinism. He ends with an interesting concept - the 'Janus gene' which has both the outward causal aspect of gene function and an inward aspect that is responsive to external cues.

Carey's book is full of illustrations and entertaining metaphors. She describes the nucleosome as DNA wrapped around "eight ping-pong balls ... like a long liquorice whip around marshmallows", and sees DNA as a film script, with plenty of room for interpretation and retakes. Carey's experience of the biotechnology industry shows in her concluding remarks on the pros and cons of our growing understanding of epigenetics for drug discovery, and on understanding the impact of diet and environment on disease.

These two bold attempts to bring epigenetics to a wide audience are at the vanguard: more books will follow as the field matures. But future authors should avoid using the words 'mystery' and 'revolution' in their titles. What makes the field so exciting is that we have new tools to address old questions. Unravelling life's mysteries? That's not revolution, it is why we become scientists in the first place. My twin brother and I are both professors studying genetics - I still wonder whether that choice was determined by genetics or the environment.

Jonathan Weitzman is professor of genetics at the Université Paris Diderot and director of the CNRS unit for Epigenetics and Cell Fate, Paris, France.

e-mail: jonathan.weitzman@univ-parisdiderot.fr

\section{Books in brief}

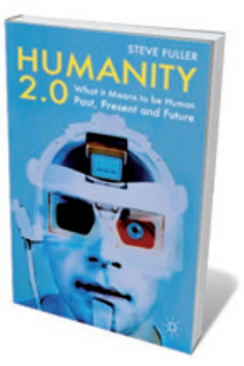

Humanity 2.0: What it Means to be Human Past, Present and Future Steve Fuller PALGRAVE MACMILLAN 288 pp. £19.99 (2011)

Forget Frankenstein and Metropolis, says sociologist Steve Fuller. Neuroscience and technology are on a collision course that will catapult us to 'transhumanity', a future in which the state of being human starts to look decidedly alien. Fuller works his way through science, policy, history and philosophy, covering human biological roots and our aspirations to transcend them; the possibility of enhanced evolution as technologies converge; a 'new theology' inspired by figures such as Jesuit palaeontologist-philosopher Pierre Teilhard de Chardin; and our necessary quest for moral horizons.

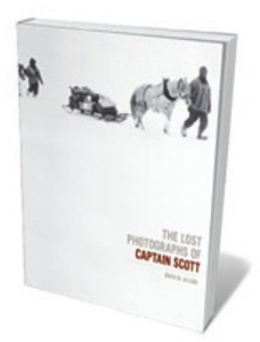

The Lost Photographs of Captain Scott

David M. Wilson LITTLE, BROWN 192 pp. \$35 (2011)

'Lost' is a refrain commonly associated with Antarctic explorer Robert Falcon Scott - lost race, lost hopes, lost lives. Now, a stunning record of his last months has been found, giving a glimpse of fieldwork at the 'final frontier'. In keeping with the research aims of the expedition, Scott shot 120 photographs between Cape Evans and Beardmore Glacier before his team's final, ill-fated push. Most of the images - icy panoramas, portraits, snaps taken on the move - are published here for the first time, with text by polar historian David M. Wilson, great-nephew of Scott's science chief Edward Wilson.

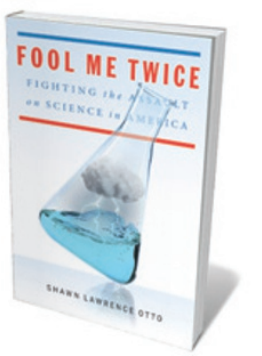

Fool Me Twice: Fighting the Assault on Science in America Shawn Lawrence Otto RODALE 384 pp. \$25.99 (2011)

Less than $2 \%$ of US senators and representatives have a scientific background, but more than $40 \%$ are lawyers. Shawn Lawrence Otto suggests that is why US policy-making is rich in rhetoric and poor in reasoning. Reminding us of the crucial separation of church and state at the birth of the United States, Otto traces shifts in national attitudes to science and technology — from early wonder through atomic-era fear to widespread rejection. That these shifts are happening precisely when big science is needed to tackle global challenges should, he says, push researchers to re-engage with politicians.

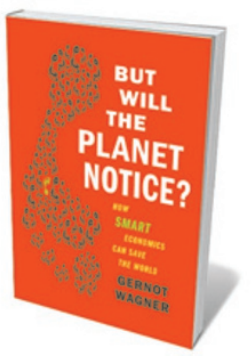

But Will the Planet Notice? How Smart Economics Can Save the World

Gernot Wagner HILL AND WANG 272 pp. \$27 (2011)

The plastic-bag militants have got it wrong, says economist Gernot Wagner. We can save the planet by cutting out scientists, politicians and environmentalists in favour of economists. It's they, he claims, who have revealed our mixed-up thinking, as we buy locally grown apples chilled for months, or clear rainforests to grow soya. Wagner calls for smart economics, such as capping pollution and paying for free resources. Billions of us must be motivated for change to be meaningful - and the best incentive is market forces, he says.

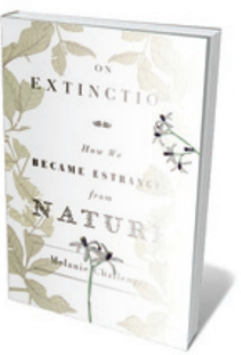

On Extinction: How We Became Estranged from Nature

Melanie Challenger GRANTA 272 pp. £20 (2011)

Writer and poet Melanie Challenger explores extinction, both biological and cultural. Roving through wild landscapes - Antarctica and the Arctic, disused Cornish tin mines and old whaling stations in South Georgia - she interweaves the science on ecological loss and climate change with histories of failed industries, extinguished languages and wars. From albatrosses on Bird Island, South Georgia, to the Inuit of Canada's Frobisher Bay, Challenger combines her meditations on our fragmenting world into a finely integrated study of loss. 